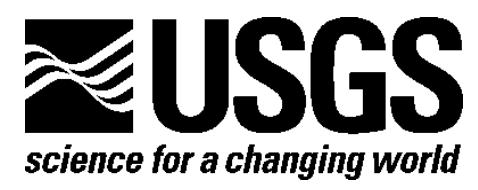

\title{
Database of the United States Coal Pellet Collection of the U.S. Geological Survey Organic Petrology Laboratory
}

By Nikolaus J. Deems and Paul C. Hackley

Open-File Report 2012-1151 


\section{U.S. Department of the Interior \\ KEN SALAZAR, Secretary}

\section{U.S. Geological Survey \\ Marcia K. McNutt, Director}

U.S. Geological Survey, Reston, Virginia: 2012

For product and ordering information:

World Wide Web: http://www.usgs.gov/pubprod

Telephone: 1-888-ASK-USGS

For more information on the USGS-the Federal source for science about the Earth,

its natural and living resources, natural hazards, and the environment:

World Wide Web: http://www.usgs.gov

Telephone: 1-888-ASK-USGS

Suggested citation:

Deems, N.J., and Hackley, P.C., 2012, Database of the United States Coal Pellet Collection of the U.S. Geological Survey Organic Petrology Laboratory: U.S. Geological Survey Open-File Report 2012-1151, 14 p., available only at http://pubs.usgs.gov/of/2012/1151.

Any use of trade, product, or firm names is for descriptive purposes only and does not imply endorsement by the U.S. Government.

Although this report is in the public domain, permission must be secured from the individual copyright owners to reproduce any copyrighted material contained within this report. 


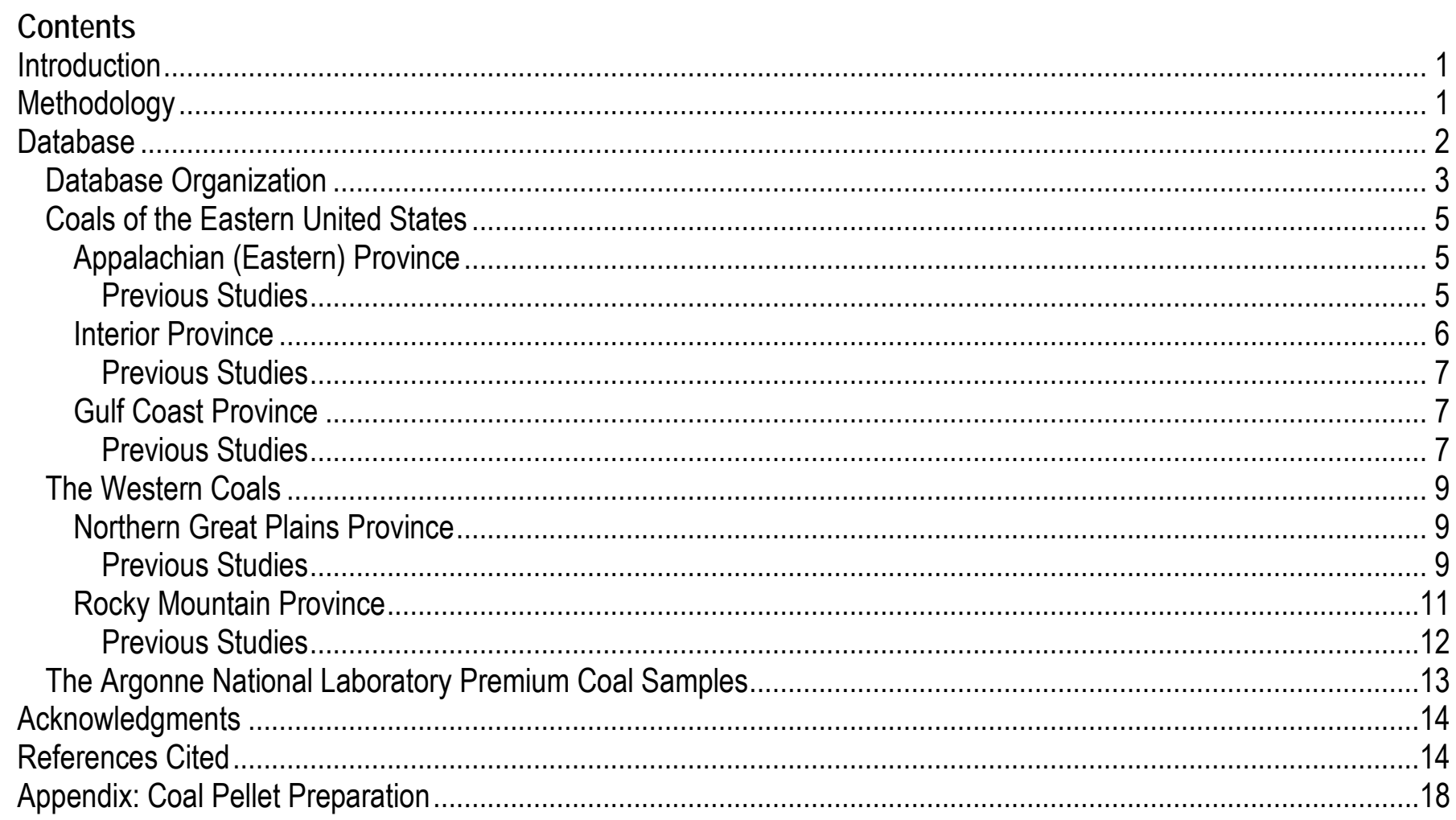

\section{Figures}

1. Photograph showing pellets organized in laboratory drawers at the project's completion. .............................. 2

2. Map showing the location and extent of the major coal fields highlighted in this report.................................. 3

\section{Table}

1. Example of organization of the coal sample database (Powder River Basin) ................................................ 4

\section{Database}

Figure 1. The database is available at http://pubs.usgs.gov/of/2012/1151/. 


\title{
Database of the United States Coal Pellet Collection of the U.S. Geological Survey Organic Petrology Laboratory
}

\author{
By Nikolaus J. Deems and Paul C. Hackley
}

\section{Introduction}

The Organic Petrology Laboratory (OPL) of the U.S. Geological Survey (USGS) Eastern Energy Resources Science Center in Reston, Virginia, contains several thousand processed coal sample materials that were loosely organized in laboratory drawers for the past several decades. The majority of these were prepared as 1-inch-diameter particulate coal pellets (more than 6,000 pellets; one sample usually was prepared as two pellets, although some samples were prepared in as many as four pellets), which were polished and used in reflected light petrographic studies. These samples represent the work of many scientists from the 1970s to the present, most notably Ron Stanton, who managed the OPL until 2001 (see Warwick and Ruppert, 2005, for a comprehensive bibliography of Ron Stanton's work). The purpose of the project described herein was to organize and catalog the U.S. part of the petrographic sample collection into a comprehensive database (available with this report as a Microsoft Excel file) and to compile and list published studies associated with the various sample sets. Through this work, the extent of the collection is publicly documented as a resource and sample library available to other scientists and researchers working in U.S. coal basins previously studied by organic petrologists affiliated with the USGS. Other researchers may obtain samples in the OPL collection on loan at the discretion of the USGS authors listed in this report and its associated Web page.

\section{Methodology}

Each sample pellet (also called briquette) in the OPL collection contains a unique field identification (ID) number. These are often in the form of two numbers: one that corresponds to a sample set or series and one that corresponds to a specific sample number within that set. Each field ID corresponds to a particular study (often several hundred pellets per study). For categorization, pellets were removed from the drawers in which they were loosely organized and grouped together on the basis of their field ID. 


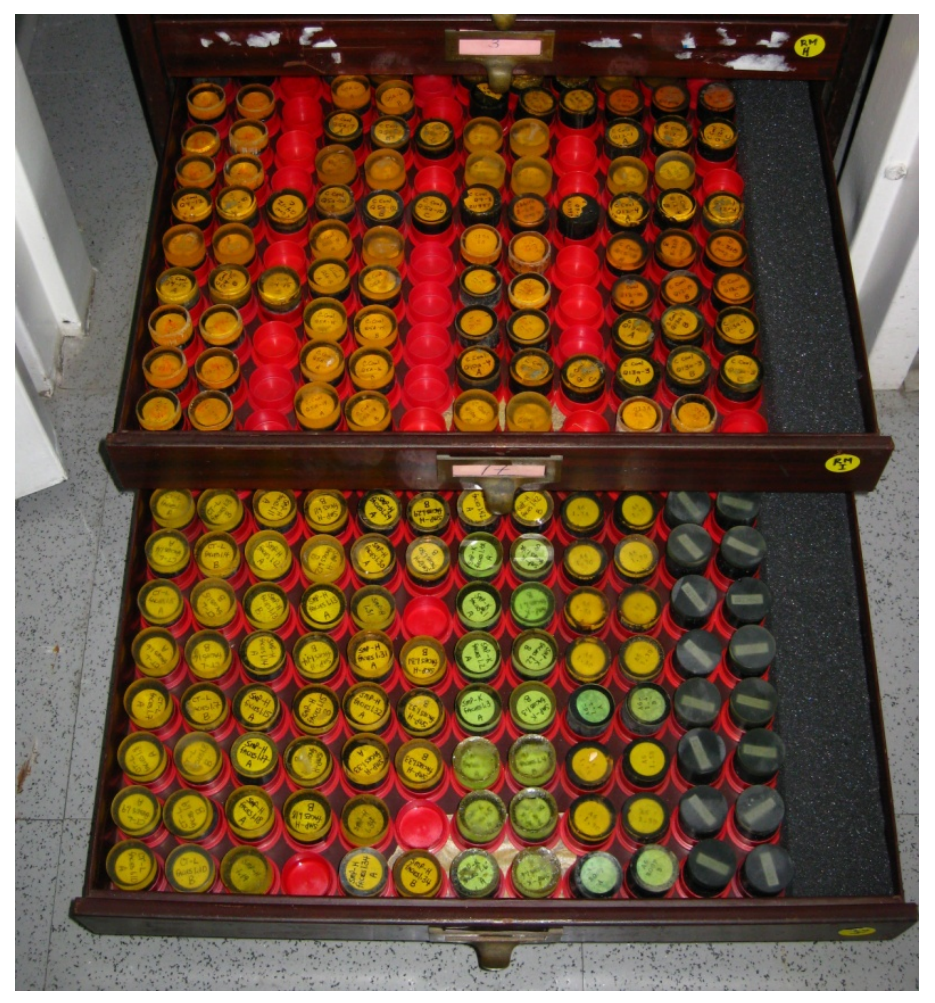

Figure 2. Figure 1. Photograph showing pellets organized in laboratory drawers at the project's completion.

The pellets were then matched to entries in laboratory records and notebooks in order to gather information regarding geographic and geologic background of the sample. Using information in USGS Bulletin 1432 (Schopf and Oftedahl, 1976) and USGS Open-File Report 96-92 (Tully, 1996) as organizational templates, each group of pellets was organized and arranged into drawers (fig. 1) on the basis of physiographic province and coal region. Each sample was entered into a spreadsheet (table 1). Depending on information availability, the pellets were categorized on the basis of State, county, geologic formation and age, coal bed, and latitude and longitude. After cataloging, each sample set was researched through a search of the published literature and a review of unpublished administrative documents kept on file in the OPL. The result is a comprehensive database of the U.S. coal pellets in the Reston USGS OPL. This report includes reference to the corresponding literature, where available, paraphrasing the major findings and conclusions of the studies.

\section{Database}

The U.S. OPL coal collection primarily comprises samples from several key physiographic locations in the United States. These samples can be separated into two broad collections, the Eastern Coals and the Western Coals (fig. 2). 


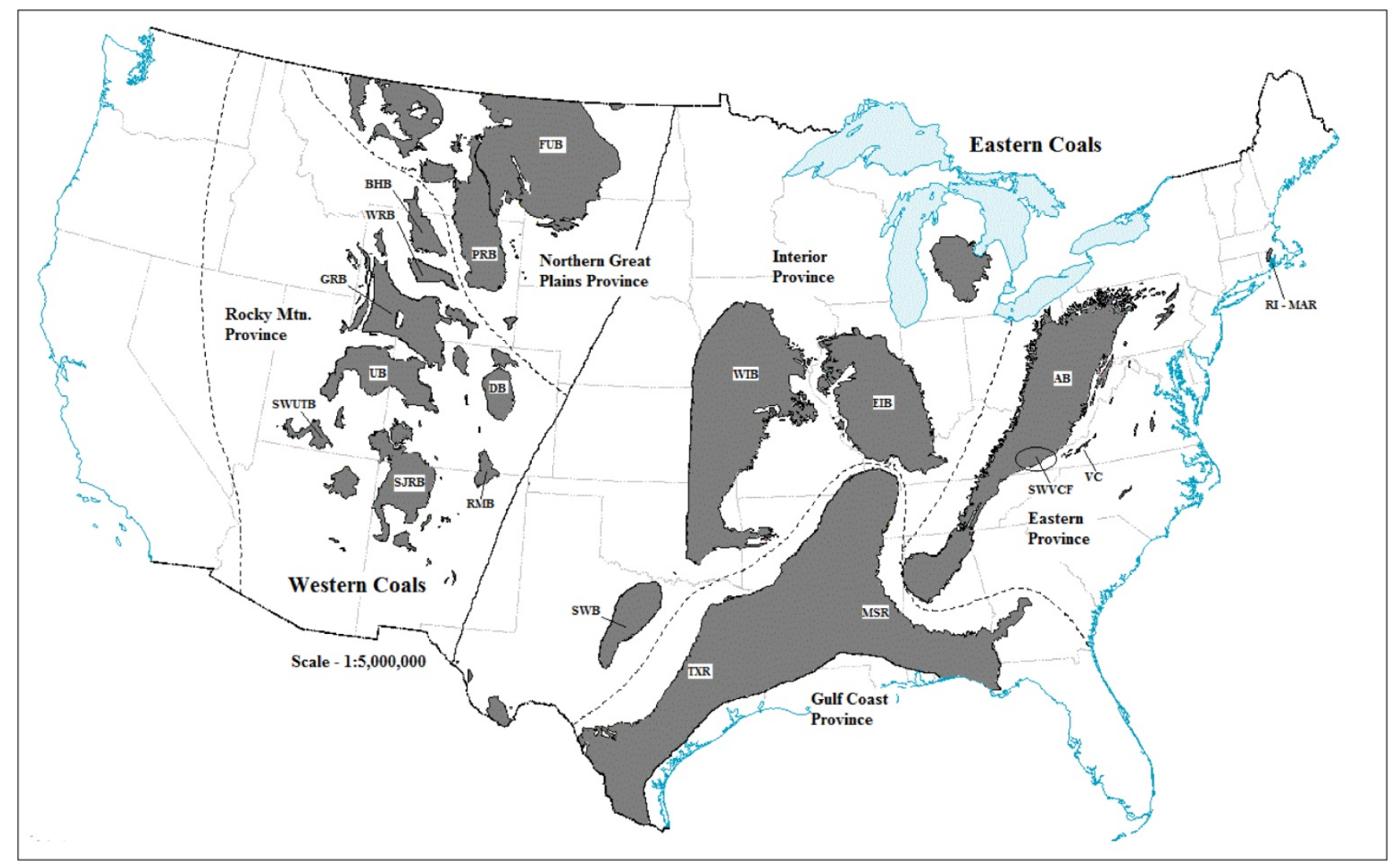

Figure 3. Figure 2. Map showing the location and extent of the major coal fields highlighted in this report. Modified from Tully (1996). Abbreviations used: RI-MAR, Rhode Island meta-anthracite; AB, Appalachian Basin; VC, Valley Coals; SWVCF, Southwest Virginia Coal Fields; MSR, Mississippi Region; TXR, Texas Region; SWB, Southwest Basin; WIB, Western Interior Basin; EIB, Eastern Interior Basin; RMB, Raton Mesa Basin; SJRB, San Juan River Basin; DB, Denver Basin; UB, Uinta Basin; GRB, Green River Basin; WRB, Wind River Basin; BHB, Bighorn Basin; PRB, Powder River Basin; FUB, Fort Union Basin; SWUTB, Southwest Utah Basin.

\section{Database Organization}

The database was created in the form of a spreadsheet with tabs corresponding to individual drawers of a cabinet containing the coal pellets located in the OPL. The drawers were separated into Eastern and Western Coals and lettered A-Q for the Eastern Coals and A-J for the Western Coals. Within each drawer, the pellets were grouped together by physiographic province (for example, Rocky Mountain Province) and coal region (for example, Wind River Region) on the basis of information found in Tully (1996). Samples were then separated on the basis of their field ID. Where available, information pertaining to sample geologic age, formation, researcher(s), and relevant published reports and unpublished documentation was included in the spreadsheet. The general organization is presented below in table 1 . The location in the database corresponds to the sample's location in the drawers. 
Table 1. Example of organization of the coal sample database (Powder River Basin).

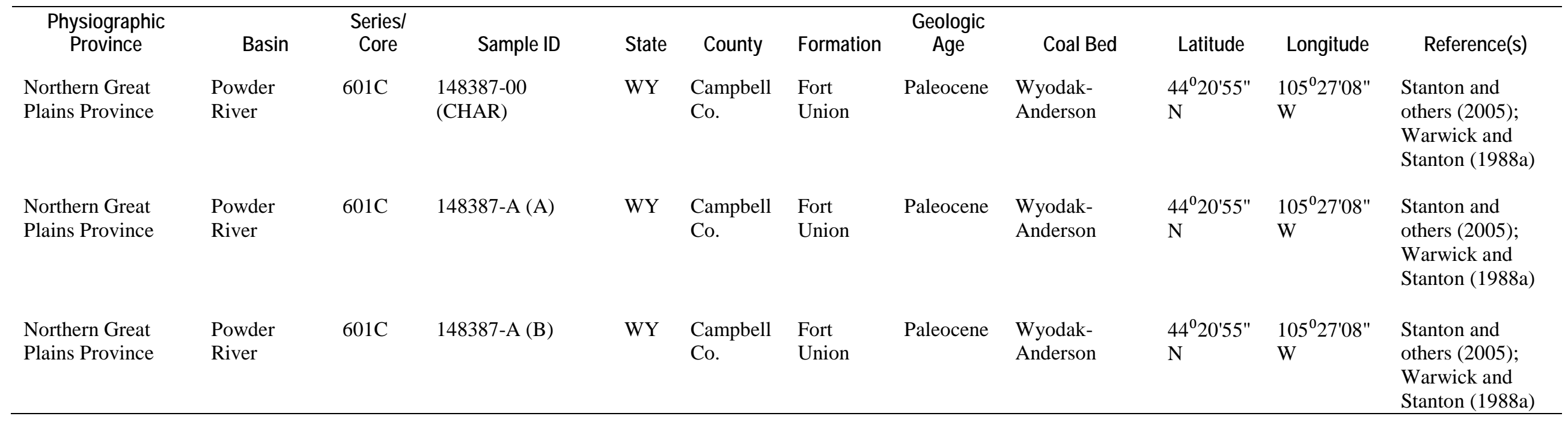




\section{Coals of the Eastern United States}

Approximately 1,170 coal samples from the Eastern United States (comprising the Appalachian (Eastern), Interior Basin, and Gulf Coast physiographic provinces (fig. 2)) are contained in the database.

\section{Appalachian (Eastern) Province}

Samples contained within the OPL collection from this area were collected primarily from the Appalachian Basin region (fig. 2). Samples (964) from parts of Pennsylvania (590 samples), Ohio (89 samples), Maryland (7 samples), West Virginia (108 samples), and Virginia (170 samples) are listed in the database. Coal from this region generally is Mississippian to Pennsylvanian in age and bituminous in rank (Tully, 1996). Nine anthracitic samples from eastern Massachusetts are also included.

\section{Previous Studies}

Work on the samples from Pennsylvania primarily was conducted for a joint study under an interagency agreement between the USGS and the U.S. Environmental Protection Agency (EPA) on geologic controls of mineral matter in coal. The primary conclusions from this study, conducted on samples from the Homer City no. 1 and Lucerne no. 6 mines (Cecil and others, 1981), were as follows:

1. The primary control on pyritic $S$ content is the geochemistry of the paleoenvironment, most importantly $\mathrm{pH}$ and the availability of $\mathrm{SO}_{4}{ }^{2-}$ and $\mathrm{Fe}$.

2. The form and size of iron disulfides are a function of different organic and inorganic geochemical processes at different stages of coalification.

3. Variations in major, minor, and trace element concentrations other than Fe, Ca, and S may have been caused by variations in the plant community, conditions in peat chemistry, and degrees of peat degradation.

4. Dominant mineral species primarily are authigenic.

5. Variations in maceral composition and mineral-matter associations also are a function of items 1 through 3, above.

See also Pierce and others (1991) and Stanton and others (1986) for more information on the Lucerne and Homer City samples.

Work on samples from West Virginia took several different studies into account. Pierce and others (1993) conducted a comparison of the petrography, palynology, and paleobotany of the Stockton coal bed, W. Va., in order to interpret paleoenvironmental conditions. They documented two successions of Lycospora spore-dominated, vitrinite-rich, liptinite-poor peat formation, succeeded by inertinite-rich peat with tree fern spores and unidentifiable plant remains. Their data were interpreted to indicate three stages of peat development, two water-laden vitrinite-rich stages followed by an inertinite-rich, slightly domed, better drained stage.

Trent and others (1982) conducted chemical analyses on 12 coal samples from the Pocahontas coal field in McDowell County, W. Va., and Tazewell County, Va. The primary conclusions from this study were as follows:

1. Eleven of the 12 samples were medium volatile bituminous coal low in ash and sulfur.

2. Chemical analysis indicated that no anomalous or harmful quantities of chemical elements were present. 
3. The samples show an increase in rank associated with increased temperatures and pressures from Appalachian mountain building; however, the increase (noted by a reduction of 22-29 percent in volatile matter over 244 meters (m) of stratigraphic distance) cannot be attributed entirely to burial and deformation.

4. Stratigraphic and lithologic studies of strata associated with the coal beds indicated the paleoenvironment during deposition was coastal-deltaic in nature.

Work on samples from Virginia (excluding the 12 samples from Trent and others (1982)) primarily was done for the purposes of test drilling for coal in the Jefferson National Forest (Englund and others, 1983a, b; Simon and Englund, 1983a, b). The purpose of this project was to determine the general characteristics of potentially recoverable coal on Federal mineral properties in the Southwestern Virginia and Valley coal fields (Valley Coals). The results of the Englund and others (1983a, b) and Simon and Englund (1983a, b) studies indicated the following:

1. Coal beds sampled in the Southwestern Virginia coal field are, in general, high volatile A bituminous coal, greater than 13,000 British thermal units per pound (Btu/lb) and contain less than 1.0 percent $\mathrm{S}$ and less than 10 percent ash.

2. Coal beds sampled in the Valley Coal fields are, in general, approximately 30 percent ash, less than 0.5 percent $\mathrm{S}$, and less than 12,000 Btu/lb. Of the 16 Valley Coal field samples, 10 are semi-anthracitic, 3 are low volatile bituminous, and 3 are medium volatile bituminous.

Information regarding the distribution and thickness of these coal beds, in addition to lithological descriptions and geophysical logs, and detailed analyses (excluding petrological and elemental analyses) are available in Englund and others (1983a, b) and Simon and Englund (1983a, b). Additional work on the same samples from the Southwestern Virginia coal field was conducted by Eble (1996) to document and compare the palynology of Lower to lower Middle Pennsylvanian coal beds. Eble concluded the following:

1. First appearance and last appearance datums of selected palynomorphs allow Lower and lower Middle Pennsylvanian coal-bearing rocks to be differentiated into broad packages, and this differentiation has been historically difficult in central Appalachian Basin coal beds of that age.

2. Early and early Middle Pennsylvanian spore assemblages in the central Appalachian Basin of Virginia can be compared and correlated to those in the Eastern and Western Interior regions (see below), as well as to coals of Western Europe.

3. Floral succession of Lycospora to Denosporites and Granulatisporites suggests a change from subaqueous to subaerial conditions over the Early to early Middle Pennsylvanian.

Published studies for the Eastern Coal samples from Ohio and Maryland were not located.

\section{Interior Province}

Samples contained within the OPL collection from this area were collected primarily from the Eastern and Western Interior basins (fig. 2) and consist of a total of approximately 96 samples. The Eastern Interior coals consist of samples from Indiana (46 samples) and Illinois (16 samples), while the Western Interior coals consist of samples from Missouri (18 samples) and Kansas (16 samples). Coal from this region generally is Pennsylvanian to Permian in age and bituminous in rank (Tully, 1996). 


\section{Previous Studies}

Work on samples from Kansas and Missouri was conducted by the State Geological Surveys of Missouri, Kansas, Iowa, and Nebraska, in cooperation with the USGS, for the purpose of investigating the coal properties and potential for coalbed methane (CBM) in the Forest City Basin (FCB) of those States (Bostic and others, 1993). The results of their investigation showed the following:

1. Several coal beds in the FCB have the potential to yield commercially viable quantities of CBM.

2. The coal sampled during this investigation is high volatile $C$ to A bituminous in rank.

3. Eleven of the coal beds sampled show methane content ranging from 72 to 97 percent.

4. Data available (geochemical and petrological) at the time of the investigation were insufficient for a thorough assessment; however, the investigation indicated the presence of CBM and, therefore, further study is warranted.

Published studies for samples from Indiana and Illinois were not located.

\section{Gulf Coast Province}

Samples contained within the OPL collection from the Gulf Coast Province were collected primarily from the Gulf Coastal Plain and the Mississippi Embayment. These two regions together comprise the Gulf Coast coal region (fig. 2), which consists of 103 samples in the OPL collection from parts of Texas (65 samples), Louisiana (13 samples), and Mississippi (25 samples). Coal from this region is generally Cretaceous to Eocene in age and lignite to subbituminous in rank (Tully, 1996).

\section{Previous Studies}

Work on samples from Texas was conducted in three areas. The first was a study of the petrography, geochemistry, and depositional setting of four samples from the San Pedro and San Tomas coal zones of the Eocene Claiborne Group in Webb County, Tex. (Warwick and Hook, 1995). The results of their findings follow:

1. The depositional setting was transitional from a sandstone-dominated, marine-influenced environment to a mudstone-dominated, freshwater environment.

2. Both Claiborne coal zones formed subaqueously in fresh to brackish lacustrine environments.

3. Petrographic and coal quality analyses indicated an anomalously high (relative to other Gulf Coast Province coals) apparent rank of high volatile bituminous.

4. Chemical analysis showed high concentrations of Be, Co, and $\mathrm{Cr}, 3$ of the 12 trace elements (As, $\mathrm{Be}, \mathrm{Cd}, \mathrm{Cr}, \mathrm{Co}, \mathrm{Hg}, \mathrm{Mn}, \mathrm{Ni}, \mathrm{Pb}, \mathrm{Sb}$, Se, and U) identified as hazardous air pollutants (HAPs) by the U.S. Clean Air Act Amendments of 1990 (Title 42 U.S. Code, Chapter 85, Section 7412; U.S. Congress, 2011).

The second study was of the petrography and trace element geochemistry of 29 samples of the Eocene San Miguel Lignite of the Jackson Group from the San Miguel mine, Atascosa County, Tex. (Warwick and others, 1996). In this study, major consideration was given to analysis of the concentrations of the 12 hazardous air pollutants. The primary conclusions of this study follow:

1. The distribution of $\mathrm{Mn}$ is inversely proportional to ash yield, a fact that indicates organic affinity for $\mathrm{Mn}$ or association with finely distributed minerals occurring intimately intermixed with organic material. 
2. The concentration of $\mathrm{Pb}$ is positively related to ash yield, a relation indicating inorganic affinity for $\mathrm{Pb}$.

3. Average whole coal concentrations for $\mathrm{As}, \mathrm{Be}, \mathrm{Sb}$, and $\mathrm{U}$ are greater than published averages for other lignites in the United States.

4. The upper and lower benches of this deposit are rich in ash and algae, a fact that suggests wetter depositional conditions as compared to the middle interval.

5. Analysis of maceral compositions suggested that conditions conducive to the degradation of woody cell material into matrix gels prevailed or that the plants were less woody and more prone to the formation of matrix gels.

6. An inertinite-rich layer suggests widespread oxidation of the peat resulting from a volcanic ash fall.

The third study was of the petrography and geochemistry of eight samples from the Eocene Manning Formation in the Gibbons Creek mine, east-central Texas (Warwick and others, 1997). The purpose of this study was to determine the association between ash yield, coal petrography, and trace element concentration in the coal and adjoining rock. Again, particular consideration was given to the 12 HAP elements. The results of this study indicated the following:

1. Average dry ash yield and S content for the two coal beds examined in this study were 29.7 percent and 2.6 percent, respectively, and average energy value was 7,832 Btu on a dry basis.

2. A positive relation in the distribution of $\mathrm{Pb}$ and $\mathrm{Sb}$ to ash yield indicated inorganic affinity of these two elements; a poor association of Be and Cd with ash yield indicated organic affinity; $\mathrm{Ni}, \mathrm{Se}, \mathrm{Hg}, \mathrm{U}$, and $\mathrm{Pb}$ clustered with most rare earth elements (REE).

3. Analyses of maceral compositions suggest that conditions were conducive to the degradation of wood cell material into matrix gels or that the plants were less woody and more prone to the formation of matrix gels.

4. Presence of siliceous sponge spicules indicated subaqueous, freshwater depositional conditions.

5. High inertinite content in the upper part of the 3,500-m-thick bed may have been associated with alteration of the peat, perhaps by volcanic ash, fire, oxidation or drying, or other biologic alteration.

Work on the 13 samples from Louisiana (OX and DH sets in the database) was conducted for the primary purpose of determining the age of the strata and the nature of the peat-forming vegetation for the coal in the uppermost Naborton Formation (Chemard Lake Lignite) of northwestern Louisiana (Frederiksen and Warwick, 1995). The findings of this study indicated the following:

1. Pollen species showed that the interval from the uppermost Naborton to the Cow Bayou Formation in the study area is late Midwayan age, middle Paleocene.

2. The Chemard Lake Lignite can be separated into two spore-pollen zones. The separation is made on the basis of palynological data showing floral succession of two distinct kinds of vegetation, grading from a dominance of psilate fern spores to a dominance of lycopod and non-psilate fern spores and triporate pollen.

3. In general, the palynology suggests that ferns, gymnosperms, and angiosperms were the predominant species in the area and therefore were responsible for the composition of the peat that formed the coal. 
Work on samples from Mississippi, specifically the Choctaw lignites (Bogue Chitto (BCDH) and Pearl River (PRDH) drill holes, 11 samples) (Windolph, 1987), was conducted for the purposes of locating, describing, and quantifying lignite resources in the Choctaw Indian Reservation. The primary conclusions of this study follow:

1. There is a potential for the discovery of additional coal beds and an extension of the known coal resources in the Pearl River community.

2. Numerous thin, high-ash lignite beds encountered in core holes on reservation properties may laterally thicken and increase in quality.

3. Presence of aquifers in the same strata as coal beds may compromise groundwater quality if mining operations are begun.

4. Existing and future land use patterns may conflict with potential mining operations.

5. Content of Se and As reported in analyses may pose environmental hazards.

6. Possible fault displacements in lignite-bearing strata may hinder the extent and recovery of existing and potential coal resources.

7. Continued exploratory drilling is necessary to further quantify existing and potential lignite resources.

Literature regarding work done on the samples from the MIS, MSDK, and MSDH5 cores (see database) from Mississippi was not located.

\section{The Western Coals}

The Western coal region can be further subdivided into the Northern Great Plains and Rocky Mountain physiographic provinces (fig. 2), and the OPL collection consists of approximately 932 samples from this area. Many of the coal regions coincide with the minor physiographic provinces within which they lie (for example, the Powder River coal region coincides with the Powder River Basin).

\section{Northern Great Plains Province}

The Northern Great Plains Province contains the Fort Union coal region of western North Dakota and eastern Montana, the Powder River coal region of central Wyoming and south-central Montana, and the North Central coal region of northwestern Montana (fig. 2). Samples within the OPL collection include coal from parts of North Dakota in the Fort Union coal region (27 samples) and from parts of Wyoming and Montana in the Powder River coal region (approximately 346 and 107 samples, respectively). Coal from these regions generally is Cretaceous to Tertiary in age and lignite to subbituminous in rank (Tully, 1996).

\section{Previous Studies}

Although studies have been conducted on the coal in the Powder River region by the USGS for over a century (Stone and Lupton, 1910), publications on the OPL collection are from 1986 to the present only.

Work on the first of these sets, database series 2630, 2651, 2682, 2694, and 2699 (approximately 78 samples in total), was conducted by Moore (1986) to characterize coal-bed splitting in the AndersonDietz coal bed of the Powder River Basin, Mont. Analysis of the Anderson-Dietz coal bed by Moore (1986) suggested the following: 
1. The split benches of the Anderson-Dietz differ from other split benches in the Appalachian and Powder River regions in that they do not appear to be affected by (diluted) or to be contemporaneous with the sediments that comprise the splits.

2. During flooding, an increase in $\mathrm{pH}$ enhanced near-surface microbial activity, which concentrated sulfur.

3. Settling of water-borne detrital sediments increased ash content.

4. In areas where peat accumulation ceased, autocompaction and subsidence allowed for accumulation of detrital sediments.

5. Areas of continued peat accumulation remained topographically high and unaffected by detrital influx but were affected by freshwater inundations. This scenario aided in degradation of plant material and increased sulfur concentration.

6. Initial peat deposits accumulating on top of detrital sediments were influenced by high $\mathrm{pH}$ conditions, and this situation resulted in a degraded, high-sulfur peat.

7. Resumption of lower $\mathrm{pH}$ conditions allowed for better preservation of plant material and a decrease in sulfur concentration.

Further work was conducted on these samples by Crowley and others (1993) primarily to identify the major factors that influenced the geochemistry of the Anderson-Dietz coal bed. Chemical analyses showed that the primary controls of the geochemistry of the Anderson-Dietz were as follows:

1. An influx of siliciclastic sediments via volcanic ash fall and fluvial processes

2. Peat-forming processes and plant material

3. An influx of epigenetic groundwater

Work on 61 samples from series 601C (see database) was conducted by Warwick and Stanton (1988a) to characterize the petrography of the Wyodak-Anderson coal bed and is tied to earlier work by the same authors (Warwick and Stanton, 1986, 1988b). Analyses of megascopic and petrographic data of this sample set showed the following:

1. The upper and lower parts of the bed contained high concentrations of wood remains (for example, humotelinite), while the middle part contained higher concentrations of material resulting from degradation and comminution (for example, eugelinite).

2. These facies were interpreted to indicate changes in chemical and biological environments during peat formation.

Work on 28 samples from the Black Thunder set was conducted by Crowley and others (1989) to determine the coal quality of the Wyodak-Anderson coal bed in the southeastern Powder River Basin. Preliminary results based on petrographic and chemical analyses showed the following:

1. Coal sampled above and below a shale parting near the top of the bed ( 3.75 meter (m) depth) differed significantly from coal sampled elsewhere in the 22-m-long core.

2. Coal sampled adjacent to the shale parting had a higher concentration of bituminite and liptodetrinite as well as pyritic and organic sulfur, while coal sampled in the lower part of the core contained more abundant fusinite and inertodetrinite.

3. Coal sampled adjacent to the parting was interpreted as having formed in a subaqueous, anaerobic environment, while coal sampled in the lower part likely formed in a subaerial environment, where the peat was more susceptible to fire or desiccation. 
Additional work on the Black Thunder sample set was conducted by Triplehorn and others (1991) following the discovery by Crowley and others (1989) of anomalously high concentrations of Zr, $\mathrm{Ba}, \mathrm{Nb}, \mathrm{Sr}$, and $\mathrm{P}_{2} \mathrm{O}_{5}$ in two zones of this core. Further analysis of the samples showed two distinct suites of minerals: a primary suite of allogenic silt-sized quartz, biotite, and zircon, and a minor suite of authigenic pyrite, calcite, kaolinite, quartz, anatase, barite, and alumino-phosphate. The discovery of these minerals in the Wyodak-Anderson led Triplehorn and others (1991) to conclude the following:

1. The allogenic minerals listed above originated from a volcanic ash fall of silica glass containing phenocrysts of quartz, biotite, zircon, feldspar, and pyroxene previously unreported due to the lack of distinct tonstein and bentonite layers.

2. The ash fall may have had a fertilizing effect on the peat, possibly contributing to the thickness (>20 m) of the Wyodak-Anderson.

3. The lack of clay in the suite of volcanic minerals suggested intense chemical leaching during the peat stage.

4. The disseminated nature of mineralization from the inferred ash fall suggested that the search for evidence of volcanic material in coal beds need not be limited to distinct, visible layers of tonstein or bentonite.

Work on 77 samples from the Smith-Anderson set was conducted by Moore and others (1990) to determine the differences in depositional settings between the Smith and Anderson coal beds based on petrography and palynology. On the basis of these criteria, the authors concluded the following:

1. The Smith coal bed formed as peat accumulated over fine-grained limestone, shale, siltstone, and discontinuous sandstone. Subsidence of these sediments resulted in a low-lying, topogenous swamp.

2. The Anderson coal bed formed as peat accumulated over thicker, more competent sandstone bodies. This scenario provided a more stable platform for accumulation and resulted in a raised, well-drained peat swamp.

Work on 27 samples from the CVPT series (see database), which incorporated further study of the 601C and Black Thunder sets, was conducted by Stanton and others (2005) for the purpose of measuring liquid fuel extraction (tar yields) by low-temperature carbonization of coal from the WyodakAnderson coal zone. The results from this study showed the following:

1. Tar yields in the Wyodak-Anderson coal zone ranged from 0.8 to 11 percent by weight and correlated strongly with the concentration of eugelinite.

2. Because the coal in the Wyodak-Anderson is all of the same rank, variation in tar yield must be a function of the composition of the samples, also suggesting that tar yield is closely related to eugelinite content.

Published studies for the Buckskin (28 samples), Crow Reservation (10 samples), Big George (35 samples), and Lake de Smet (29 samples) areas, and the Fort Union coal region were not located.

\section{Rocky Mountain Province}

The Rocky Mountain Province contains the Bighorn Basin region of northwestern Wyoming, the Wind River region of central Wyoming, the Green River region of southwestern Wyoming and northwestern Colorado, the Uinta region of eastern Utah and west-central Colorado, the Southwestern Utah region of Utah, the San Juan River region of northwestern New Mexico and southwestern Colorado, the Denver region of central Colorado, and the Raton Mesa region of south-central Colorado 
and northeastern New Mexico (fig. 2). Samples within the OPL from the Rocky Mountain Province include coal collected from each of the States in the regions mentioned above, except the Denver and Raton Mesa regions. Coal in the Rocky Mountain Province generally is Cretaceous to Tertiary in age and subbituminous to bituminous in rank (Tully, 1996). Although they are not spatially located in the Rocky Mountain Province, 10 samples from Alaska also are included in the Western Coal part of the OPL collection.

\section{Previous Studies}

Twenty-one samples from the Bighorn Basin region (Grass Creek or GC series) include those collected from the Grass Creek mine, Wyo. (Roberts and others, 1994). Roberts and others (1994) investigated coal and clastic facies of the Paleocene coal-bearing succession exposed in the Grass Creek coal mine. The major findings of their investigation follow:

1. Ash yields and maceral composition indicated the coal beds developed in low-lying, topogenous mires.

2. Coarsening-upward successions of mudrock and sandstone overlying coal beds in the lower sections indicated that peat accumulation was repetitively disrupted by influx of sediment, likely the result of crevasse splays.

3. Cessation of peat accumulation in the Grass Creek mine area is marked by a diamictite, likely the result of a debris flow, overlying the uppermost coal bed.

Work on samples from the Green River region was conducted in the Rock Springs coal field, primarily on coal in the Almond Formation (Al Fm series, 170 samples in database) and the Vermillion Creek (VC series, 16 samples in database) coal bed of the Wasatch Formation.

Work on the VC series was conducted by Henry Roehler for the purposes of providing geologic information regarding the occurrence, quality, and quantity of coal in the Rock Springs coal field. The results of his investigations were extensive and published in 12 chapters in Roehler and Martin (1987). The work included studies of the following:

1. Structure and stratigraphy of the Niland Tongue and associated Eocene formations

2. Sedimentology and ecology of the Vermillion Creek coal bed

3. Petrographic and physical properties of the Vermillion Creek coal bed

4. Elemental and organic geochemistry of the Vermillion Creek coal bed

5. Sulfur isotopes of the Vermillion Creek coal bed

6. Radioactivity of the Vermillion Creek coal bed and its splits and partings

Work on Almond Formation coal also was chiefly conducted by Henry Roehler; however, his publications (Roehler, 1978a, b; Robinson and Roehler, 1979; Roehler, 1988) do not mention specific sample IDs and cannot be definitively linked to the samples in the USGS OPL collection.

Published studies of work on nine samples from Rock Springs (referred to as ENV in database) (also worked on by Henry Roehler, according to laboratory hardcopy records) were not located.

Work on samples from the Uinta region (C Coal set, see database) was conducted by Crowley and others (1989) on the C Coal bed of the Mancos Shale in the Emery coal field, Utah, for the purpose of determining the effects of volcanic ash on maceral composition and chemistry. Petrographic and chemical analyses from this study showed the following:

1. Alteration of volcanic glass and minerals led to the formation of tonstein layers composed of kaolinite and smectite. 
2. Abundant inertinites below the tonstein layers indicated well-drained conditions prior to the ash fall, while abundant vitrinites above indicated poorly drained conditions after the ash fall. This is likely the result of the alteration of the ash to clay, forming a semi-impermeable layer conducive to the ponding of surface water.

3. The abundance of elements such as $\mathrm{Zr}, \mathrm{Nb}$, Th, and Ce in coal samples adjacent to the tonsteins suggested that the ash fall was the source of these elements and had a significant impact on the chemistry of the C Coal bed.

Work on 77 samples from the Southwestern Utah region (CT and SMP series, see database) was conducted by several scientists for the purpose of relating coal deposition and quality to climate, tectonics, and eustasy (Hettinger and McCabe, 1992a). Preliminary results and interpretations from this project were given in abstracts by Hettinger and McCabe (1992a, b) and Pierce and others (1992). Sedimentological descriptions, geophysical logs, and preliminary interpretations on depositional environment were given in Hettinger (1993). Detailed analyses and interpretations on sedimentology and deposition in sequence stratigraphic context were given in Hettinger (1995) in which he concluded the following:

1. Primary bedding structures and fossil assemblages indicated interbedded shoreface, tidal, and coastal plain depositional environments.

2. Depositional facies relations indicated long periods of uninterrupted peat accumulation with limited influx of fluvial or marine deposits.

3. Association of stacked shoreface parasequences with thick, relatively clean coal deposits interbedded with tidal deposits suggested peat accumulation in raised mires on a coastal plain dissected by tidal creeks and estuaries.

Detailed palynological analysis of the CT and SMP series was given in Nichols (1995). Results from his analysis showed the following:

1. Two regional palynostratigraphic zones occur in the Straight Cliffs Formation of the Kaiparowits Plateau (Nyssapollenites albertensis in the lower part of the Straight Cliffs and Proteacidites retusus in the upper part).

2. Marine dinocysts and nonmarine strata suggested tidally influenced deposition during transgressive and highstand systems tracts.

3. Palynological analysis of coal samples suggested that ferns, sphagnum, and certain angiosperms were the predominant vegetation in these paleomires.

Published studies for work done on any of the samples from the Wind River Region were not located.

\section{The Argonne National Laboratory Premium Coal Samples}

In addition to the categories listed above, the OPL also contains within its collection a set of the eight coals from the Argonne National Laboratory's Premium Coal Sample Program. The purpose of the Argonne program was to provide researchers with high-quality samples of a limited number of coals selected to represent the significant differences among available coal types mined in the United States (Vorres, 1990). Collection began in January 1985 and continued through November 1986. The samples were collected from seven States located in three of the coal regions, as follows (numbers correspond to the numbering of the Argonne National Laboratory):

1. Appalachian coal region, Pennsylvania, Upper Freeport coal 
2. Powder River coal region, Wyoming, Wyodak-Anderson coal

3. Western Interior coal region, Illinois, Illinois no. 6/Herrin coal

4. Appalachian coal region, Pennsylvania, Pittsburgh coal

5. Appalachian coal region, Virginia, Pocahontas no. 3 coal

6. Uinta coal region, Utah, Blind Canyon coal

7. Appalachian coal region, West Virginia, Lewiston-Stockton coal

8. Fort Union coal region, North Dakota, Beulah-Zap coal

Each of the samples underwent homogeneity, proximate and elemental, and stability analyses for the purposes of the Argonne project. Results from these analyses along with supporting information can be found in Vorres (1990) and on the Argonne National Laboratory's Premium Coal Samples Web site (http://www.anl.gov/PCS). Each of the Argonne Laboratory premium coal samples is placed in the appropriate drawer according to the regional organizational scheme presented in this report.

\section{Acknowledgments}

Students Rachel Gesserman and Mahmoud Eljack helped compile the preliminary lists of samples contained in the OPL. Technical reviews by Sharon Swanson and Peter Warwick and editorial comments by John Watson improved the manuscript.

\section{References Cited}

ASTM International, 2011a, D2797/D2797M-09 Standard practice for preparing coal samples for microscopical analysis by reflected light: Annual book of ASTM standards: Petroleum products, lubricants, and fossil fuels; Gaseous fuels; coal and coke, sec. 5, v. 5.06: ASTM International, West Conshohocken, PA, p. 454-458.

ASTM International, 2011b, D2799-09 Standard test method for microscopical determination of the maceral composition of coal: Annual book of ASTM standards: Petroleum products, lubricants, and fossil fuels; Gaseous fuels; coal and coke, sec. 5, v. 5.06: ASTM International, West Conshohocken, PA, p. 464-469.

ASTM International, 2011c, D2798-09a Standard test method for microscopical determination of the vitrinite reflectance of coal: Annual book of ASTM standards: Petroleum products, lubricants, and fossil fuels; Gaseous fuels; coal and coke, sec. 5, v. 5.06: ASTM International, West Conshohocken, PA, p. 459-463.

Bostic, J., Brady, L., Howes, M., Burchett, R., and Pierce, B.S., 1993, Investigation of the coal properties and the potential for coal-bed methane in the Forest City Basin: U.S. Geological Survey Open-File Report 93-576, 44 p.

Cecil, C.B., Stanton, R.W., and Dulong, F.T., 1981, Geology of contaminants in coal: Phase I Report of Investigations: U.S. Geological Survey Open-File Report 81-953-A, 91 p.

Crowley, S.S., Ruppert, L.F., Belkin, H.E., Stanton R.W., and Moore, T.A., 1993, Factors affecting the geochemistry of a thick, subbituminous coal bed in the Powder River Basin: volcanic, detrital, and peat-forming processes: Organic Geochemistry, v. 20, no. 6, p. 843-853.

Crowley, S.S., Stanton, R.W., and Ryer, T.A., 1989, The effects of volcanic ash on the maceral and chemical composition of the C coal bed, Emery Coal Field, Utah: Organic Geochemistry, v. 14, no. 3, p. 315-331. 
Crowley, S.S., Stanton, R.W., and Warwick, P.D., 1989, Coal quality of a core from the WyodakAnderson coal bed, southeast Powder River Basin, Wyoming: a preliminary study: U.S. Geological Survey Open-File Report 89-81, 32 p.

Eble, C.F., 1996, Lower and lower Middle Pennsylvanian coal palynofloras, southwestern Virginia: International Journal of Coal Geology, v. 31, p. 67-113.

Englund, K.J., Weber, J.C., Thomas, R.E., Windolph, J.F. Jr., and Dryden, J.W., 1983a, Test drilling for coal in 1982-83 in the Jefferson National Forest, Virginia. Part III, Lithologic descriptions and geophysical logs of coreholes in the Valley coal fields, Bland, Botetourt, Montgomery, Pulaski, Smyth, and Wythe Counties, Virginia: U.S. Geological Survey Open-File Report 83-637, 249 p. (Also available at http://pubs.usgs.gov/of/1983/0637/.)

Englund, K.J., Windolph, J.F. Jr., Weber, J.C., Thomas, R.E., and Dryden, J.W., 1983b, Test drilling for coal in 1982-83 in the Jefferson National Forest, Virginia, Part I: Lithologic descriptions and geophysical logs of coreholes in the southwestern Virginia coal field, Dickenson, Lee, Scott, and Wise Counties, Virginia: U.S. Geological Survey Open-File Report 83-628, 377 p.

Frederiksen, N.O., and Warwick, P.D., 1995, Palynology of Paleocene lignite beds and associated detrital strata from Louisiana and Mississippi: U.S. Geological Survey Open-File Report 95-208, 22 p.

Hettinger, R.D., 1993, Sedimentological descriptions and geophysical logs of two 300-m cores collected from the Straight Cliffs Formation of the Kaiparowits Plateau, Kane County, Utah: U.S. Geological Survey Open-File Report 93-270, 50 p.

Hettinger, R.D., 1995, Sedimentological descriptions and depositional interpretations, in sequence stratigraphic context, of two 300-meter cores from the Upper Cretaceous Straight Cliffs Formation, Kaiparowits Plateau, Kane County Utah: U.S. Geological Survey Bulletin 2115-A, p. A1-A32. Hettinger, R.D., and McCabe, P.J., 1992a, Testing new coal models: the 1991 Kaiparowits Plateau drilling project, in Carter, L.M.H., ed., USGS Research on Energy Resources, 1992, Program and Abstracts: U.S. Geological Survey Circular 1074, 34 p.

Hettinger, R.D., and McCabe, P.J., 1992b, Depositional setting of coal in a Cretaceous high-stand deposit - Facies analyses of core from the Kaiparowits Plateau, Utah: Abstracts volume, Society of Economic Paleontologists and Mineralogists 1992 Theme Meeting, Mesozoic of the Western Interior, p. 31-32.

Moore, T.A., 1986, Characteristics of coal bed splitting in the Anderson-Dietz coal seam (Paleocene), Powder River Basin, Montana: Lexington, Ky., University of Kentucky Master’s Thesis, 109 p.

Moore, T.A., and Stanton, R.W., 1985, Coal petrographic laboratory procedures and safety manual: U.S. Geological Survey Open-File Report 85-20, 68 p., accessed January 20, 2012, at http://pubs.usgs.gov/of/1985/0020/report.pdf.

Moore, T.A., Stanton, R.W., Pocknall, D.T., and Flores, R.M., 1990, Maceral and palynomorph facies from two Tertiary peat-forming environments in the Powder River Basin, U.S.A.: International Journal of Coal Geology, v. 15, no. 4, p. 293-316.

Nichols, D.J., 1995, Palynostratigraphy in relation to sequence stratigraphy, Straight Cliffs Formation (Upper Cretaceous), Kaiparowits Plateau, Utah: U.S. Geological Survey Bulletin 2115-B, 21 p. Pierce, B.S., and Stanton, R.W., 1990, Coal quality and compositional characteristics of the Upper Freeport coal bed, Pennsylvania, source of the Argonne \#1 Premium Sample: U.S. Geological Survey Open File Report 90-697, 28 p.

Pierce, B.S., Stanton, R.W., and Eble, C.F., 1991, Facies development in the Lower Freeport coal bed, west-central Pennsylvania, U.S.A: International Journal of Coal Geology, v. 18, no. 1-2, p.17-43. 
Pierce, B.S., Stanton, R.W., and Hettinger, R.D., 1992, Sampling and characteristics of Cretaceous coal from the Kaiparowits Plateau, southern Utah, in Proceedings; The Society for Organic Petrology, $9^{\text {th }}$ annual meeting, Abstracts and Programs: p. 49-50.

Pierce, B.S., Stanton, R.W., and Eble, C.F., 1993, Comparison of the petrography, palynology, and paleobotany of the Stockton coal bed, West Virginia and implications for paleoenvironmental interpretations: Organic Geochemistry, v. 20, no. 2, p.149-166.

Pontolillo, J., and Stanton, R.W., 1994, Coal petrographic laboratory procedures and safety manual II: U.S. Geological Survey Open-File Report 94-631, 69 p., accessed January 20, 2012, at http://pubs.usgs.gov/of/1994/0631/report.pdf.

Roberts, S.B., Stanton, R.W., and Flores, R.M., 1994, A debris flow deposit in alluvial, coal-bearing facies, Bighorn Basin, Wyoming, USA: Evidence for catastrophic termination of mire: International Journal of Coal Geology, v. 25, p. 213-241.

Robinson, L., and Roehler, H.W. 1979, Hypothetical coal resources of the Almond Formation in the Rock Springs coal field, Wyoming: U.S. Geological Survey Open-File Report 79-588, 11 p.

Roehler, H.W., 1978a, Correlations of coal beds in the Fort Union, Lance, and Almond Formations in measured sections on the east flank of the Rock Springs uplift, Sweetwater County, Wyoming: U.S. Geological Survey Open-File Report 78-248, 1 sheet.

Roehler, H.W., 1978b, Correlations of coal beds in the Fort Union, Almond, and Rock Springs Formations in measured sections on the west flank of the Rock Springs uplift, Sweetwater County, Wyoming: U.S. Geological Survey Open-File Report 78-395, 1 sheet.

Roehler, H.W., 1988, The Pintail coal bed and Barrier Bar G; A model for coal of barrier bar-lagoon origin, Upper Cretaceous Almond Formation, Rock Springs coal field, Wyoming: U.S. Geological Survey Professional Paper 1398, 60 p.

Roehler, H.W., and Martin P.L., eds., 1987, Geological investigations of the Vermillion Creek coal bed in the Eocene Niland Tongue of the Wasatch Formation, Sweetwater County, Wyoming: U.S. Geological Survey Professional Paper 1314 A-L, 202 p.

Schopf, J.M., and Oftedahl, O.G., 1976, The Reinhardt Thiessen coal thin-section slide collection of the U.S. Geological Survey; Catalog and notes: U.S. Geological Survey Bulletin 1432, 58 p.

Simon, F.O., and Englund, K.J., 1983a, Test drilling for coal in 1982-83 in the Jefferson National Forest, Virginia Part II: Analyses of coal cores from the southwestern Virginia coal field: U.S. Geological Survey Open-File Report 83-620, 25 p.

Simon, F.O., and Englund, K.J., 1983b, Test drilling for coal in 1982-83 in the Jefferson National Forest Part IV: Analyses of coal cores from the Valley coal fields: U.S. Geological Survey Open-File Report 83-626, 16 p.

Stanton, R.W., Pierce, B.S., Moore, T.A., and Ruppert, L.F., 1985, Descriptions and correlations of coal bed facies, Lower Freeport(?) coal bed, west-central Pennsylvania: U.S. Geological Survey Open-File Report 85-393, 55 p.

Stanton, R.W., Cecil, C.B., Pierce, B.S., Ruppert, L.F., and Dulong, F. T., 1986, Geologic processes affecting the quality of the Upper Freeport coal bed, west-central Pennsylvania: U.S. Geological Survey Open-File Report 86-173, 22 p.

Stanton, R.W., Warwick, P.D., and Swanson, S.M., 2005, Tar yields from low-temperature carbonization of coal facies from the Powder River basin, Wyoming, U.S.A.: International Journal of Coal Geology, v. 63, no. 1-2, p. 13-26.

Stone, R.W., Lupton, C.T., 1910, The Powder River coal field, Wyoming, adjacent to the Burlington Railroad: U.S. Geological Survey Bulletin B 381-B, p. 115-136. 
Taylor, G.H., Teichmüller, M., Davis, A., Diessel, C.F.K., Littke, R., and Robert, P., 1998, Organic Petrology: Berlin, Germany, Gerbrüder Borntraeger, 704 p.

Trent, V.A., Medlin, J.H., Coleman, S.L., and Stanton, R.W., 1982, Chemical analyses and physical properties of 12 coal samples from the Pocahontas field, Taxewell County, Virginia, and McDowell County, West Virginia: U.S. Geological Survey Bulletin 1528, 37 p.

Triplehorn, D.M., Stanton, R.W., Ruppert, L.F., and Crowley, S.S., 1991, Volcanic ash dispersed in the Wyodak-Anderson coal bed, Powder River Basin, Wyoming: Organic Geochemistry, v. 17. no. 4, p. 567-575.

Tully, J.K., 1996, Coal fields of the conterminous United States: U.S. Geological Survey Open-File Report 96-92, 1 map, scale 1:5,000,000, accessed June 1, 2012, at http://pubs.usgs.gov/of/1996/of96092/.

U.S. Congress, 2012, Air pollution prevention and control: 42 U.S. Code, Chap. 85, Sect. 7412, accessed January 20, 2012, at http://uscode.house.gov/download/pls/42C85.txt.

Vorres, K.S., 1990, The Argonne Premium Coal Sample Program: Energy \& Fuels, v. 4, p. 420-426.

Warwick, P.D., and Stanton, R.W., 1986, Depositional controls on the geometry of the WyodakAnderson coal bed, northeastern Wyoming: U.S. Geological Survey Circular 974, p. 71-72.

Warwick, P.D., and Stanton, R.W., 1988a, Petrographic characteristics of the Wyodak-Anderson coal bed (Paleocene), Powder River Basin, Wyoming, U.S.A.: Organic Geochemistry, v. 12, p. 389-399.

Warwick, P.D., and Stanton, R.W., 1988b, Depositional models for two Tertiary coal-bearing sequences in the Powder River Basin, Wyoming, U.S.A.: Journal of the Geological Society of London, v. 145, no. 4, p. 613-620.

Warwick, P.D., and Hook, R.W., 1995, Petrography, geochemistry, and depositional setting of the San Pedro and Santo Tomas coal zones: anomalous algae-rich coals in the middle part of the Claiborne Group (Eocene) of Webb County, Texas: International Journal of Coal Geology, v. 28, p. 303-342.

Warwick, P.D., and Ruppert, L.F., 2005, TSOP twentieth anniversary meeting, Washington DC area, 2003: International Journal of Coal Geology, v. 63, p. 1-12.

Warwick, P.D., Crowley, S.S., Ruppert, L.F., and Pontolillo, J., 1996, Petrography and geochemistry of the San Miguel lignite, Jackson Group (Eocene), south Texas: Organic Geochemistry, v. 24, no. 2, p. 197-217.

Warwick, P.D., Crowley, S.S., Ruppert, L.F., and Pontolillo, J., 1997, Petrography and geochemistry of selected lignite beds in the Gibbons Creek mine (Manning Formation, Jackson Group, Paleocene) of east-central Texas: International Journal of Coal Geology, v. 34, p. 307-326.

Windolph, J.F., Jr., 1987, Lignite resource assessment of the Choctaw Indian Reservation in Jones, Kemper, Leake, Neshoba, and Newton Counties, Mississippi: Administrative Report to the Bureau of Indian Affairs and Mississippi Band of Choctaw Indians, 205 p. 


\section{Appendix}

\section{Coal Pellet Preparation}

The coal pellets contained in the OPL laboratory collection were prepared by crushing samples to a desired top size, usually 20 mesh (850- $\mu$ m sieve opening), per ASTM D2797 Standard practice for preparing coal samples for microscopical analysis by reflected light (ASTM D2797 has changed little since the samples in this collection were prepared; the most recent version of the standard is ASTM International, 2011a). Prior to 2005 (applicable to all of the samples discussed in this report), coal pellets prepared in the OPL laboratory were formed by mixing particulate coal with an epoxy resin binder (current laboratory practice uses a heat-setting thermoplastic powder as the mounting medium). In general, the typical preparation method was to, after crushing, (1) mix approximately 12 to 15 grams of the coal powder with sufficient resin plus hardener to wet all coal particulate surfaces, (2) pour the coal plus epoxy mixture into a stainless steel mold and use a hydraulic press to remove trapped air bubbles, (3) allow the sample to cure, and (4) prepare the samples for examination using a succession of grinding and polishing stages (for the most recent version of the standard used see ASTM International, 2011a). A Buehler Ecomet 4 variable speed grinder-polisher has been used in the OPL laboratory since approximately 2000 for grinding and polishing. Following final polish, coal pellets typically are stored in a desiccator overnight prior to microscopic study (maceral/mineral point count studies generally follow ASTM D2799 (most recently described in ASTM International, 2011b), vitrinite reflectance studies follow ASTM D2798 (most recently described in ASTM International, 2011c), blue light evaluation techniques are outlined in Taylor and others, 1998). Some of the samples discussed herein were etched with oxidizing agents; this technique and other OPL laboratory procedures were discussed in Moore and Stanton (1985) and Pontolillo and Stanton (1994). 